\title{
中枢における言葉の認知と表出の相互作用
}

\author{
児 嶋 久 剛・平 野 滋・楯 谷一 郎 - 井 上 真 郷 \\ 内藤泰・庄司和彦
}

\section{Interaction between Perception and Production in the Central Cortical Processing of Speech}

\author{
Hisayoshi Kojima, Shigeru Hirano, Ichiro Tateya, \\ Masato Inoue, Yasushi Naito and Kazuhiko Shoji
}

There is a close relationship between perception and the production of language. In order to examine that of the central nervous system in the brain, a PET study was performed on healthy adults. The auditory association area, the Broca's area, was extensively activated during listening to speech. Neural activity was also observed in the cerebellum, in addition to Broca's area, motor area, and the supplementary motor area during reading aloud with auditory feedback. However, little activity in the auditory association area was noted compared with that during passive listening. These results suggest that one's own speech is not processed for perception by the auditory association area during speaking. During reading aloud with distorted feedback of input speech, activity increased in the auditory association area and in the motor area but was reduced in the supplementary motor area. Through these observations, we have found two different speech modes; feedforward control managed primarily by the supplementary motor area and feedback control by the auditory association area. It is suggested that interactions among functional areas of the brain for speech take place through numerous trial and errors during the language acquisition period and while the neural network is established. A PET study on patients with various functional voice disorders was also performed. It showed distinct differences in the activities of functional areas compared with those of healthy adults. Investigation of central cortical processing in the brain is important to elucidate the pathogenesis of patients with hearing and speech disorders.

Key words : 言語中枢, 表出, 認知, PET, 機能性発声障害

はじめに

言語の認知と表出の間には密接な相互作用が存在し，こ れなくしては中枢での言語機能は発達し得ない.先天聾の 子が聴覚の刺激なしに成長すると重大な構音障害をきたす ことはよい例である.

言語処理にかかわる中枢の研究はフランスの外科医ブロー カに端を発する ${ }^{1)}$. その後もウエルニッケ ${ }^{2)}$, ペンフィー ルド3) やその研究を引き継ぐ多くの研究者がこの分野の研 究にかかわった。これらの研究結果をまとめたのが図 1 で ある ${ }^{4)}$. 脳には外側淟, 中心溝と呼ばれる特徵的な溝が二 つあるが, 言語処理にかかわる中枢は外側溝の周囲に存在 する，耳に音が入るとまず一次聴覚野に運ばれる．ウエル ニッケ野を含む上側頭回は聴覚連合野と呼ばれ，言語処理 といった高次の情報処理機能がおこなわれる，一方，言葉 を話す場合にはまず，ブローカ野で言葉のもととなる内言 語が生成される．上前頭回の内側中部の補足運動野で発話 運動を企画し, 中心前回の運動野が活動して発声構音器官
を動かすとされている。しかし，これまでの研究では活動 中の脳を侵襲なく観察するということが技術的に問題であっ たためにこれ以上の成果をなかなかあげることができなかっ た.ところが, 近年の脳機能画像法といった技術革新によ りこれが評価できるようになってきた．われわれはその一 つであるポジトロン断層法を用いることで言語中枢におけ る表出と認知の中枢機構, とりわけ今まで手のつけられて いなかった脳機能局在の相互作用を解明しようと試みた.

\section{言語処理にかかわる脳の機能局在}

言葉を聞いてそれを声を出さずに頭の中で繰り返してい るときの中枢処理機構をみたのが図 2 である ${ }^{5)}$. 健常人 12 人で統計的に有意な活動を示した部位を描出したものであ るが, 従来認知に関与するといわれていたウェルニッケ野 だけでなく聴覚連合野全体が，しかも左だけでなく右も強 く活動している．もう一つの注目すべき点は声を出してい ないにも関わらずブローカ野が活動していることであり， 認知と発話の中枢機構に何らかの相互作用があることが示 
唆された.

一方, 発話中の脳活動を示したのが図 3 である ${ }^{6)}$. 文章 を読んでいるために視覚野が活動している．また，言葉の 表出に関与するといわれていたブローカ野が活動している が, これに加えて小脳, 運動野, 補足運動野などに活動が 見られる．興味あるのは自ら発する声を聞いているにもか かわらず聴覚連合野が賦活されていないことである. 従来 からの研究と考えあわせるとブローカ野で言葉がつくられ, 補足運動野で構音運動を企画し, 運動野の指令によって構 音器官が運動して言葉を表出するというプロセスは理解で きる.また小脳は運動調節にかかわっていると考えられる が，不思議なことは発話時には自分の発する声を聞いてい るにも関わらず聴覚連合野が働かないのである。ここに認 知と表出の中枢相互作用を解明する手がかりがあると思わ れる.

\section{フィードバック制御と前向き制御}

言葉を話すという動作も随意運動のひとつである。そこ で, すこし本題からそれるが, 随意運動を習熟する過程を 考えてみる7). たとえば箸を持って豆のような小さいもの をつまむ運動を想定してみると，初めてその運動を行おう とするときは, 絶えず試行錯誤しながら行うが, 運動に慣 れてくると次第にすばやくスムーズに行えるようになる. 試行錯誤によって誤差を調整しながらおこなう運動はフィー ドバック制御（図４ａ），すばやくおこなう運動は前向き 制御（図 4 b ）と呼ばれている.未熟なときの運動はどう してもフィードバック制御にならざるを得ないが, 運動の 指令を出す前向き制御装置が賢くなれればすばやい運動が おこなえる，つまり，われわれが運動を習熟する過程は図 $4 \mathrm{c}$ のようになると考えられる. 未熟なときにはフィード バック制御で運動するが, 繰り返しのフィードバック制御 での誤差調節が，同時に前向き制御装置を調整した結果， 最終的にフィードバック制御のない前向き制御で正確な運 動がより早くおこなえるようになるのである．言葉を話す という過程においても同様の制御が働いていると考えられ る. 我々が観察した健常人での発話時の脳機能で聴覚連合 野が活動しなかったのは, 前向き制御で発話しているから であろうと思われる。

\section{発話運動と聴覚フィードバック}

それでは, 発話中に聴覚フィードバックがかかると構音 運動にどのような変化が生じるのであろうか? これに関し ては, delayed auditory feedback を用いた心理実験が よい手がかりを与えてくれる8,9).すなわち, 自ら発した 声を100〜300ミリ秒の遅延回路を通して聞かせると，話者 はしどろもどろにしか話せなくなる，このことは，構音動 作が速すぎてこれをその都度聴覚を介してフィードバック しながら話しつづけることは不可能であることを示す.

そこで，話者の発する声を加工して聞かせてやるという 方法を用いてフィーバック制御時の発話時脳活動を観察す
ることを試みた。健常成人 6 名を対象に, 日常会話文のリ ストを音読してもらい，その時の脳活動を PETを用いて


では，自分の声を $300 \mathrm{~Hz}$ ローカットフィルターを通して 歪ませ, 課題 2 では 100 ミリ秒の遅延回路を通して被験者 に聞かせながら音読を続けさせた。 その結果，いずれの課 題においても一次聴覚野, ブローカ野, 運動野, 小脳に加 え聴覚連合野に有意な活動を認めた（図 $5 ， 6$ ）。また， 先の通常の発話時にみられた補足運動野の活動は消失して いた。これらの歪み処理語音の聴取による言語では, 課題 1 では流暢に発話できるのに対し課題 2 では発話運動が大 きく障害された．PETで観察された 2 つの課題での脳活 動の差をみると, 課題 2 で聴覚連合野と運動野の活動がよ り強く認められた（図 7 ). すなわち, 課題 2 での自分の 声の聞こえ方が予期するものと大きくずれたために，課題 1 より聴覚連合野が強く反応し過㮃な運動野の活動を招い たものと考えられた．前述の通常の発話時に聴覚連合野の 活動が認められなかったことを考え合わせると, みずから 発した声が予期せぬ聞こえ方をするときに聴覚フィードバッ クが働くものと考えられ，この中枢神経機構は言語獲得期 に自分の声を聞きながら構音の修正を行う言語の学習に不 可欠なものと推察された.

運動に関連する領域では, 課題 1，2で運動野の活動上 昇と補足運動野の活動低下が認められたが，特に補足運動 野の抑制は注目に值する。この領域は運動のプログラミン グに関与するとされており ${ }^{11)}$, 獲得された言語様式ではこ のプログラムに沿った発話運動がおこなわれているのに対 し，予期する声と違った声がモニターされるや聴覚連合野 が活動を増すと同時にあらかじめプログラムされた運動企 画はキャンセルされて, より運動野に負担のかかる従来と は異なった運動様式を採用するようになるものと考えられ た。

言語発達期にある幼少児の脳では，あらかじめ企画され たプログラムどおりの運動領域，すなわち補足運動野は未 形成であり，おそらくこの時期には聴覚連合野の活動が極 めて活発で, 運動野に繰り返しフィードバックをかけなが ら発話を行っているものと考えられ，ひとたびプログラム ができてしまうと聴覚フィードバックは不要になるものと 考えられた。

\section{疾患の病態解明の足がかり}

中枢における病態が不明な疾患に痙攣性発声障害という 病気がある.この病気は喉頭に何の器質的な変化もないに もかかわらず，声を出そうとするとつっかえつっかえして 出せないというものである。一部では，この病気は喉頭に 限局した形の筋緊張異常, ジストニアであるともいわれて いる.そこでこの両者の発話時の脳機能を比較した. 図 8 は㾪攣性発声障害の例であるが, 発話時にも言語認知機構 である聴覚連合野の活動が認められる，健常者の通常発話 と明らかに異なった所見である. 
それに対しジストニアの発声障害をみてみると, 聴覚連 合野は活動しておらず，補足運動野に活動が認められる (図 9 ). 小脳も活動しているが, 健常者と比較すると小脳 の活動が強く，運動の過㮃な調節を疑わせる所見が得られ


疾患には脳機能画像上明らかな違いがある可能性が考えら れた。

$$
\text { ま と め }
$$

本論文では, 言語獲得期には発話時の聴覚フィードバッ クが重要で, 逆に言語機能が確立されると発話時に聴覚の 抑制がおこるという認知と表出の相互関係を明らかにした. この結果は聴覚言語障害のリハビリテーションを考える上 でも重要な資料になると思われた.

また, これを観察することで, 従来機能性発声障害とい われていたような病態の不明な発声障害を解明する可能性 があることがわかった.

本研究の一部は, 平成12年度厚生科学研究費感覚器障害 研究事業補助金, 及び, 平成12年度文部省科学研究費（基 盤研究(B)(2), 課題番号11470356）によりなされた.

\section{文献}

1) Broca $P:$ Sur le siege de la faculte du langage articule. Bull Soc Anthropol Paris 6:377 393, 1865.

2) Wernicke C: Der aphasische symptomenkomplex. Cohn \& Weigert, Breslau, 1874.

3) Penfield W \& Roberts L: Speech and brain mechanism. Princeton University Press,
Princeton, 1959.

4）平野 滋ほか：発話時の発話関連領域と聴覚領の脳 活動一ポジトロン断層法による観察一。耳鼻臨床 89 : 1401 1406, 1996.

5) Hirano $\mathrm{S}$ et al : Cortical activation by monaural speech sound stimulation demonstrated by positron emission tomography. Exp Brain Res $113: 75 \sim 80,1997$.

6) Hirano $S$ et al : Cortical speech processing mechanisms while vocalizing visually presented languages. NeuroReport 8:363 367, 1996.

7) Ito $\mathrm{M}: \mathrm{A}$ new physiological concept on cerebellum. Rev Neurol (Paris) 146:564 569, 1990.

8) Chase RA : Effect of delayed auditory feedback on the repetition of speech sounds. $J$ Speech Hearing Dis 23:583 590, 1958.

9) Lee BS: Effects of delayed speech feedback. J Acoust Soc Am 22: 824 826, 1950.

10) Hirano $\mathrm{S}$ et al : Cortical processing mechanisms for vocalization with auditory verbal feedback. NeuroReport 8:2379 2382, 1997.

11) Roland PE et al : Supplementary motor area and other cortical areas in organization of voluntary movements in man. $\mathrm{J}$ Neurophysiol $43: 118 \sim 136,1980$.

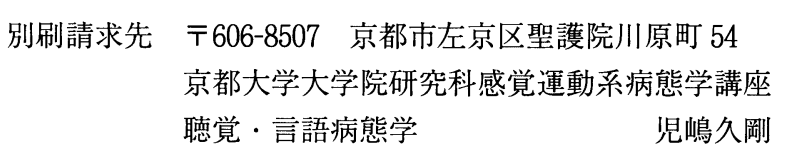






言語聴取

図 1 言語機能に関する脳の機能局在. (文献 4 より改変)

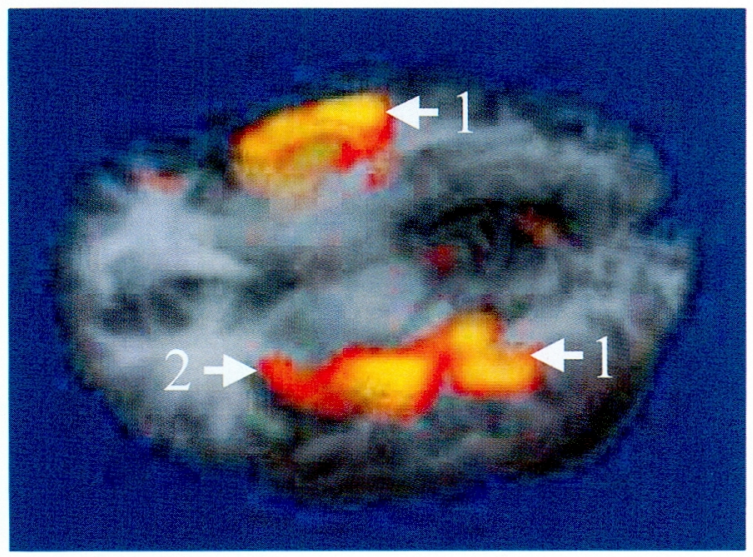

図 2 言語聴取時の脳活動. 矢印 $1:$ 聴覚連合野, 矢印 $2:$ ブローカ野.

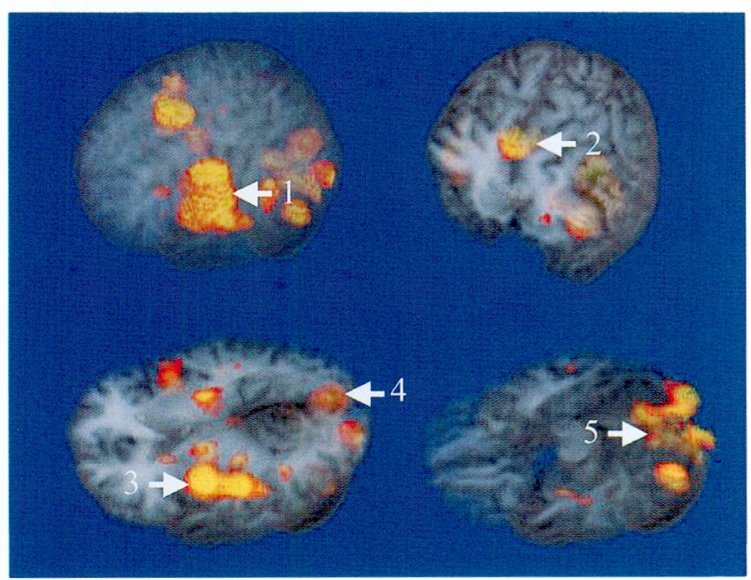

図 3 発話時の脳活動.

矢印 $1:$ 運動野, 矢印 $2:$ 補足運動野, 矢印 $3:$ ブ ローカ野, 矢印 $4:$ 視覚野, 矢印 $5:$ 小脳. (a) フィードパック制御装置

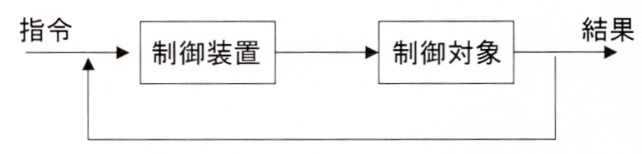

(b) 前向き制御装置

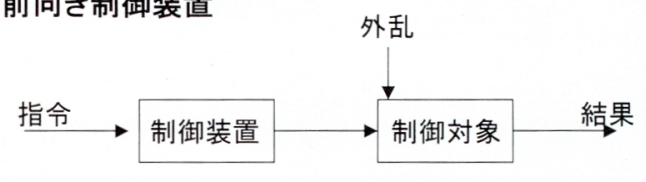

(c) 適合制御装置



図 4 随意運動の制御装置. (文献 7 より改変)

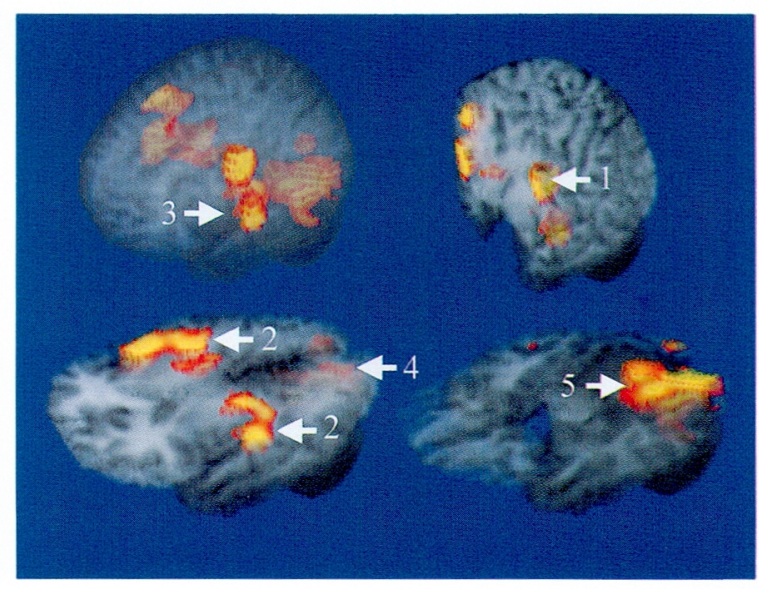

図 5 課題 1（ローカットフィルタ）における脳活動. 矢印 1 : 運動野, 矢印 2 : 聴覚連合野, 矢印 $3:$ : ローカ野, 矢印 $4:$ 視覚野, 矢印 $5:$ 小脳. 


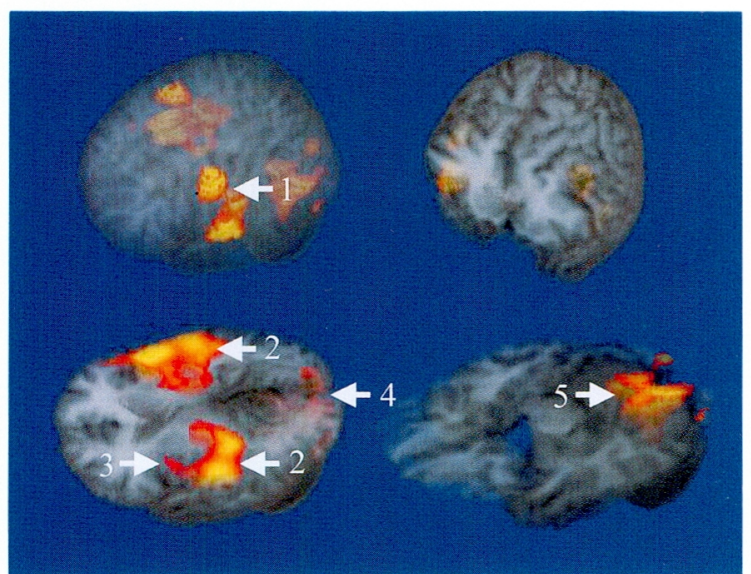

図 6 課題 2 (遅延回路)に扔ける脳活動.

矢印 1 ：運動野, 矢印 2 ：聴覚連合野, 矢印 3：フ ローカ野, 矢印 $4:$ 視覚野, 矢印 5 : 小脳

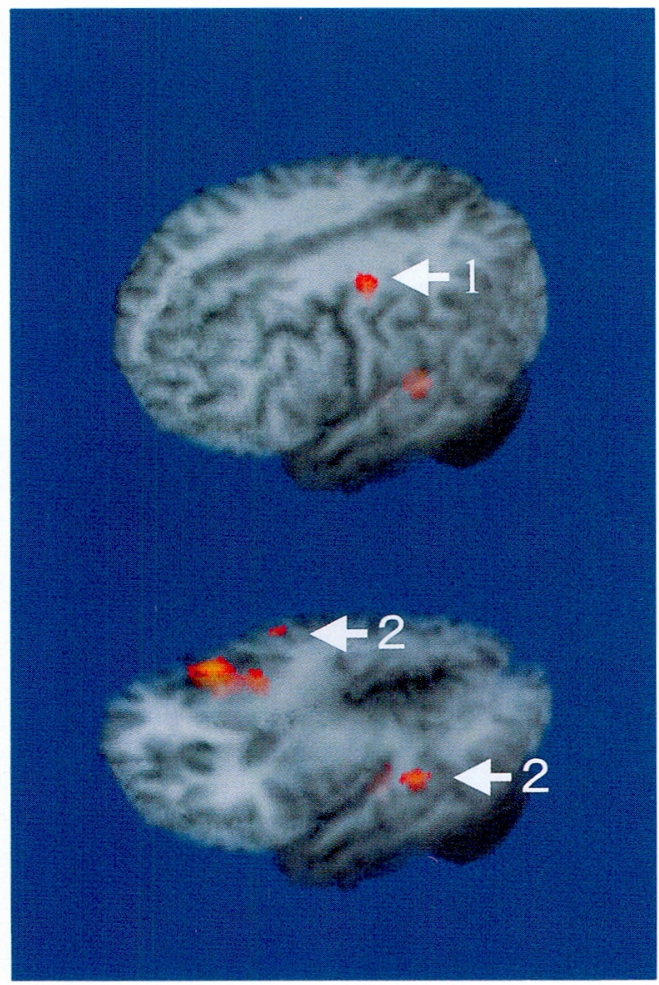

図 7 課題 2 一課題 1 .

矢印 1 : 運動野, 矢印 $2 ：$ 聴覚連合野



図 8 瘃攣性発声障害患者の発話時の脳活動。(上段) 補 足運動野（破線矢印）の活動を認めず。(下段）聴 覚連合野（矢印）の活動を認める。

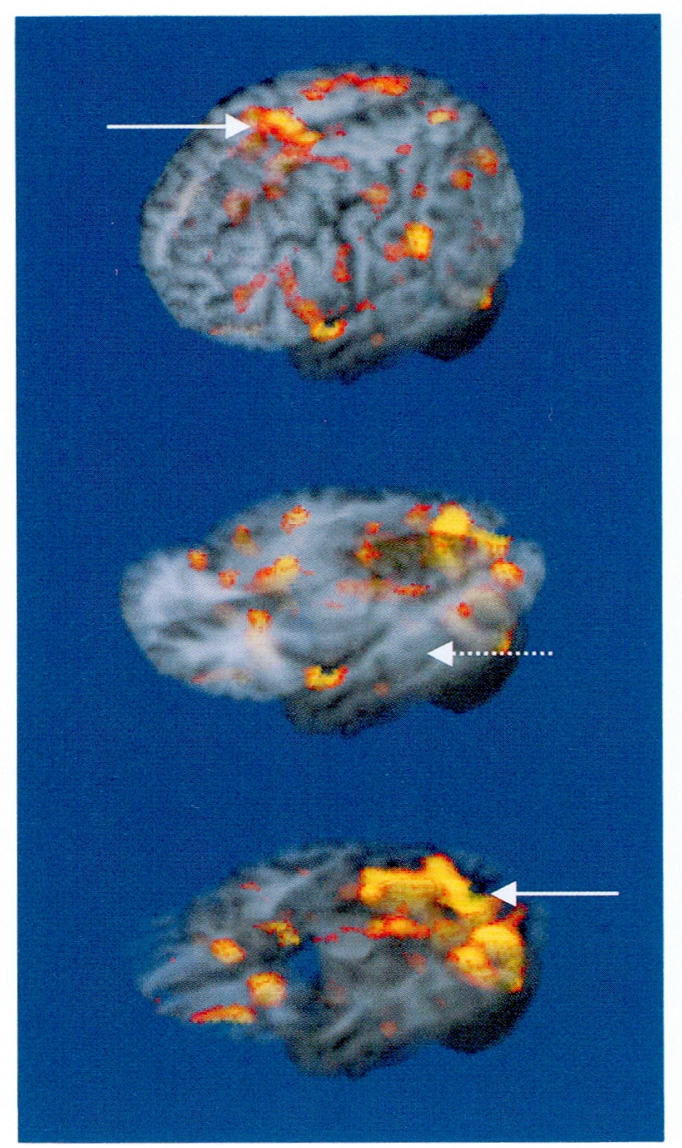

図 9 ジストニア患者の発話時の脳活動. (上段) 補足運 動野 (矢印) の活動を認应。(中段) 聴覚連合野 の活動を認めず.(下段）小脳の活動が強い. 